\title{
A comunicação integrada de marketing no ciberespaço: adaptações possíveis na assessoria de publicidade e propaganda e na assessoria de imprensa diante da virtualidade
}

\section{The integrated marketing communication in cyberespace: possible adaptations of advertising and press advisories before the virtuality}

Gilson Ciarallo'

Andre Sá de Mattos ${ }^{2}$
1 Doutor em Sociologia pela Universidade de Brasília (2005), mestre em Sociologia pela Universidade de Brasília (2000) e graduado em Relações Internacionais pela Universidade de Brasília (1997). Atualmente é professor no Instituto Ceub de Pesquisa e Desenvolvimento do Centro Universitário de Brasília - UniCEUB. Email: gilson.ciarallo@uniceub.br.

2 Oficial da Marinha do Brasil, atualmente cursando especialização em Gestão da Comunicação nas Organizações no UniCEUB. E-mail: sahdemattos@gmail.com.

\section{Resumo}

A assessoria de publicidade e propaganda se utiliza das características de sinergia e convergência, comuns entre a Comunicação Integrada de $\mathrm{Ma}$ rketing (CIM) e o ciberespaço, em seus produtos virtuais conforme cada fase do ciclo de vida do produto-marca. Essa utilização visa os resultados financeiros da organização e é adaptada conforme o fluxo de recursos financeiros disponíveis para a comunicação em cada fase desse ciclo de vida. A utilização das tarefas ou jobs em comunicação corporativa, dispostos em redes no ciberespaço, proporciona uma complementaridade nas mensagens e uma alternância na liderança de cada job entre as assessorias, conforme as mudanças das fases do ciclo de vida do produto-marca. A assessoria de imprensa, por sua vez, para reforçar a imagem organizacional, adota um relacionamento diferenciado com os jornalistas com o uso da "sala de imprensa" e de certas ferramentas proporcionadas pela internet para possibilitar o monitoramento simultâneo de redes sociais. Ao abordar esses assuntos, este artigo tem o objetivo de estabelecer as potencialidades desse ambiente virtual, a serem utilizadas conceitualmente em cada uma dessas duas áreas da CIM, de modo a proporcionar ferramentas para um "salto" de imagem da organização e, para isso, utiliza-se da pesquisa bibliográfica e documental para dar continuidade aos artigos intitulados "A comunicação integrada de marketing no ciberespaço: as características do ambiente virtual que são favoráveis à integração da comunicação organizacional" e "A comunicação integrada de marketing no ciberespaço: as modificações ou adaptações possíveis na assessoria de relações públicas diante da virtualidade", respectivamente, e conclui que, ao estabelecer as potencialidades desse ambiente virtual, a serem utilizadas conceitualmente nessas duas assessorias componentes da comunicação integrada, haverá condições e ferramentas para o "salto" de imagem da organização.

Palavras-chave: Assessoria de publicidade e propaganda. Assessoria de imprensa. Ciberespaço. Comunicação integrada de marketing.

\section{Abstract}

The advertising advisory uses the characteristics of synergy and convergence between integrated marketing communications and cyberspace, in 
their virtual goods as each phase of the life cycle of the product-brand. This aims the financial results of the organization and is adapted as the flow of financial resources available for communication at each stage of life cycle. The use of tasks or jobs in corporate communications, arranged in cyberspace networks, offering complementary messages and a shift in the leadership of each job between the staffs, according to the changing phases of the lifecycle of the product-brand. The press, in turn, to enhance organizational image, adopts a differentiated relationship with journalists using the "press room" and certain tools offered by the Internet to allow simultaneous monitoring of social networks. This article uses the bibliographic and documentary research in a continuation of the articles entitled "The integrated marketing communications in cyberspace: the characteristics of the virtual environment that favored the inclusion of organizational communication." And “ The integrated marketing communication in cyberspace: the modifications or adjustments possible in the public affairs advisory before the virtuality. "respectively, and concludes that, in establishing the potential of this virtual environment, to be used in these two advisories in integrated communication components, and tools will be able to "jump" the organizational image.

Keywords: Advertising advisory. Press advisory. Cyberspace. Integrated marketing communication.

\section{Introdução}

Diante do fato de que os dois aspectos que a Comunicação Integrada de Marketing ${ }^{3}$ (CIM) pode fazer uso no ambiente virtual, por similaridade de conceitos - sinergia e convergência, estudam-se ambos os conceitos em cada uma das assessorias componentes da CIM. Com o olhar na atuação das assessorias de publicidade e propaganda e a assessoria de imprensa no ciberespaço, a sinergia, nesse caso, origina-se no esforço constante e multifacetado para melhorar gradativamente a comunicabilidade da rede, enquanto que na CIM, a sinergia diz

3 A comunicação integrada de "marketing" (CIM) é definida como uma filosofia que direciona a convergência das diversas áreas (de comunicação organizacional) permitindo uma atuação sinérgica. Pressupõe uma junção da comunicação institucional, da comunicação mercadológica e da comunicação interna que formam o mix, o composto da comunicação organizacional. (KUNSCH, 2003, p. 150, grifo nosso). respeito à gestão coordenada e sinérgica dos esforços humanos e organizacionais. Com esse mesmo olhar, o conceito de convergência no ciberespaço diz respeito àquela proporcionada pela organização em rede que o ciberespaço acolhe e, na CIM, há a convergência de esforços das suas assessorias componentes sobre a tarefa.

Com base nesses conceitos, a CIM deve efetuar as suas tarefas, ou jobs, ${ }^{4}$ sob a forma de redes computadorizadas, com a assessoria líder como mediadora da rede virtual em cada job para conseguir o resultado esperado.

O presente artigo tem o objetivo geral de estabelecer as potencialidades desse ambiente virtual a serem utilizadas conceitualmente em cada área da CIM, particularmente na assessoria de publicidade e propaganda e na assessoria de imprensa, de modo a proporcionar ferramentas para um "salto" de imagem da organização.

Procedeu-se, neste artigo, à pesquisa documental em sites, textos impressos e disponíveis na internet, bem como nos artigos de relevância para o entendimento dos assuntos; procedeu-se também à pesquisa bibliográfica não somente em livros e periódicos considerados como clássicos, mas também nos mais atuais ao abordarem cada um dos temas: a CIM e o ciberespaço. Isso para que a pesquisa conduzida pudesse prover um embasamento teórico que possibilitasse uma agregação de pontos de vistas comuns na tentativa de efetuar uma ligação indissolúvel do primeiro com o segundo tema, área por área da CIM.

\footnotetext{
${ }_{4}^{4}$ job é o termo, em língua inglesa, designativo, em comunicação, da tarefa ou conjunto de tarefas relativas a um determinado trabalho, em agência de trabalho ou birô (RABAÇA; BARBOSA, 2001, p. 402). Um dos instrumentos de controle de tarefas é o cronograma. O cronograma nada mais é que "[...] um plano que especifica os períodos de tempo, nos quais as atividades (jobs) têm que ser executadas." (HAMPTON, 1980, p. 127 apud KUNSCH, 2003, p. 224). No cronograma, os jobs têm seu início e fim, seus responsáveis, e seu detalhamento de execução (KUNSCH, 2003, p. 226).
} 


\section{A assessoria de publicidade e propaganda com foco no ciberespaço}

Inicialmente, deve-se fazer a diferença conceitual entre publicidade ${ }^{5}$ e propaganda ${ }^{6}$ de forma a entender como essa assessoria da CIM pode comportar-se no ciberespaço. Enquanto a publicidade tem sua atuação ligada a tornar público algum produto, serviço ou marca, a propaganda, diferentemente, tem sua atuação ligada à mobilização do consumidor ou cliente por persuasão (RABAÇA; BARBOSA, 2001, p. 598). Busca-se a conquista da mente do consumidor por argumentação ou por convencimento de ideias que levarão ao chamado share of mind, ${ }^{7}$ quanto à opção por um produto, serviço ou marca (PINHEIRO; GULLO, 2009, p. 57-59).

Observa-se, para isso, as fontes de oportunidade no mercado, quais sejam: fornecer algo escasso; fornecer, de maneira nova, ou melhor, um produto ou serviço existente; e fornecer um novo produto ou serviço (KOTLER, 1999, p. 55). Para isso, a busca de uma propaganda voltada para apresentar ao público-alvo a imagem organizacional com uma associação ao diferencial em inovação e no valor agregado. Finalmente, as redes sociais de diferentes espécies contribuíram de forma intensa para

5 “[...] a publicidade mostra-se mais abrangente no sentido de divulgação (tornar público, informar, sem que isso implique, necessariamente, em persuasão)". (RABAÇA; BARBOSA, 2001, p. 598).

6 Propaganda é a comunicação persuasiva. Conjunto de técnicas e atividades de informação e de persuasão destinadas a influenciar as opiniões, os sentimentos e as atitudes do público num determinado sentido. [...] No Brasil, e em alguns outros países de língua latina, as palavras propaganda e publicidade são geralmente usadas com o mesmo sentido, e esta tendência parece ser definitiva, independentemente das tentativas de definição que possamos elaborar em dicionários ou em livros acadêmicos (RABAÇA; BARBOSA, 2001, p. 598).

7 Chama-se share of mind ao estudo do nível de lembrança da marca na mente dos consumidores no mercado. Consideramse, para isso, os seguintes fatores: o que lembram e quantas vezes lembram sobre a marca, por meio da comunicação de marketing, para se chegar ao nível de recall da marca. (TAVARES, 2007, p.1). É a medida de aferição do conhecimento da marca de produto ou instituição que um determinado público tem na memória, em dado momento (RABAÇA; BARBOSA, 2001, p. 671). a consolidação do meio de inovação ${ }^{8}$ e seu dinamismo, assegurando a comunicação de ideias, circulação de trabalho e troca de experiências sobre inovação tecnológica e iniciativas empresariais arrojadas e, principalmente, as suas respectivas ações em propaganda (CASTELLS, 1999, p. 481).

Para facilitar essa discussão, dentro do ciberespaço, apesar da diferença conceitual exposta ao referir-se à propaganda, engloba-se o conceito de publicidade dentro do conceito de propaganda. Pelo mesmo motivo, ao falar de públicos, utilizar-se-á, para a propaganda, a palavra "consumidor" ou a palavra "cliente", com os seus significados englobando o "público-alvo da organização" (RABAÇA; BARBOSA, 2001, p. 598).

A propaganda pode ter seu foco com uma utilização, dentro da CIM, conforme se processam as fases de introdução e crescimento do ciclo de vida ${ }^{9}$ de um produto-marca (Figura 4). Em cada fase deve-se dar uma visão panorâmica das ações da assessoria de publicidade e propaganda dentro do job, possibilitando que as demais assessorias troquem informações sobre seus produtos de forma a tornar a comunicação o mais complementar possível. Tal ação evita duplicidades e mantém a credibilidade da organização por integração de esforços. Isso ocorre por ser a assessoria de publicidade e propaganda muito efetiva para despertar a atenção e o interesse do consumidor ou cliente, sendo com isso, preferencialmente, a assessoria inicialmente líder do job e aquela que irá fazer a apresentação introdutória do produto de comunicação com um site ou blog propagandístico, no ciberespaço. Tal ação aproveita a característica de convergência do ciberespaço para apresentar uma só ideia persuasiva de modo que ela seja claramente entendida (PINHEIRO; GULLO, 2009, p. 59-62).

8 O que define a especificidade de um meio de inovação é a sua capacidade de gerar sinergia [em associação à característica de sinergia do ciberespaço], isto é, o valor agregado resultante não do efeito cumulativo dos elementos presentes no meio, mas de sua interação. Os meios de inovação são as fontes fundamentais de inovação e de geração de valor agregado no processo de produção industrial da era da informação (CASTELLS, 2010, p. 478, grifo nosso).

9 O ciclo de vida do produto-marca é o ciclo de fases por que passa o produto, serviço ou marca, na estrutura do mercado, desde o seu surgimento, na sua participação de mercado (market share), e na sua descontinuidade no mercado. As fases do ciclo de vida do produto-marca são: introdução, crescimento, maturidade e declínio (PINHEIRO; GULLO, 2009, p. 41). 
Figura 1 - Gráfico do ciclo de vida do produto-marca

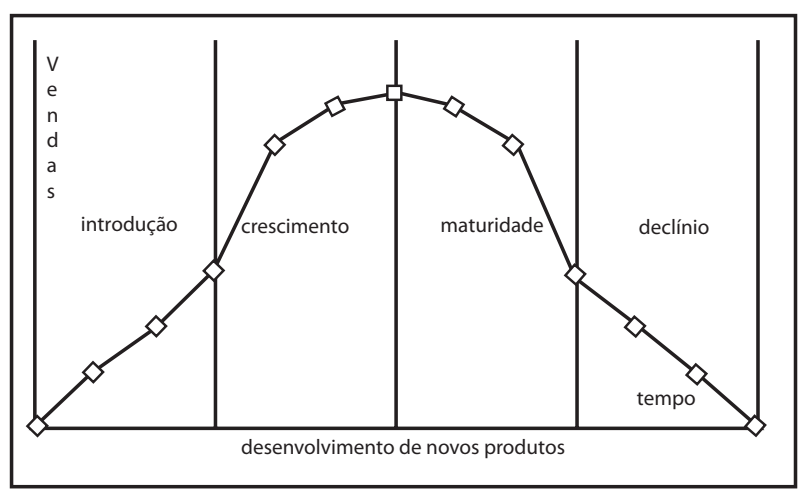

Fonte: Pinheiro e Gullo (2009, p. 41).

Diferentemente das RP, a assessoria de publicidade e propaganda está diretamente focada na melhoria da imagem organizacional para a obtenção de resultados financeiros favoráveis:

\begin{abstract}
A função da propaganda é enviar uma mensagem correta com um conteúdo necessário, para criar a fazer a manutenção de uma imagem, obter sua aceitação, sua preferência e sua presença na mente do consumidor ou cliente. E quando o esforço de propaganda dá o resultado esperado, então a repercussão é imediata nas vendas e pode-se dizer que apoiou o crescimento de vendas (PINHEIRO; GULLO, 2009, p. 57, grifo nosso).
\end{abstract}

Com a visão no resultado em vendas, a inserção da assessoria de publicidade e propaganda no ciberespaço se faz nas três primeiras fases do ciclo de vida do produto-marca (PINHEIRO; GULLO, 2009, p. 41). Em cada uma dessas fases um dos objetivos genéricos da propaganda é buscado. A propaganda, como atividade de comunicação voltada para resultados financeiros, possui os seguintes objetivos genéricos:

De maneira genérica, os objetivos da propaganda podem ser agrupados em três categorias básicas: cognitivos, afetivos e comportamentais. [...] No primeiro caso, predomina o caráter informativo da mensagem, mais indicado em situações de lançamento [na fase de introdução no ciclo de vida do produto-marca], especialmente de novas categorias. No segundo o foco é estabelecer ou reforçar uma relação afetiva da empresa ou do produto com o público-alvo, gerando preferência; portanto, esse objetivo é indicado para produtos ou empresas já estabelecidos, além de visar à manutenção do processo de divulgação. [coincidente com a fase de crescimento no ciclo de vida do produto-marca] No terceiro caso, a comunicação tem um caráter mais persuasivo, buscando provocar algum tipo de reação favorável ou oferecer um estímulo, o que ocorre com mais frequência em ações promocionais. [nas fases de crescimento e maturi- dade no ciclo de vida do produto-marca] Essa categoria também é indicada para produtos já estabelecidos no mercado (OGDEN; CRESCITELLI, 2010, p. 57, grifo nosso).

Essa inserção por fase do ciclo de vida do produto visa, essencialmente, diante das oportunidades de marketing, ${ }^{10}$ aproveitar os objetivos genéricos da propaganda e as características de sinergia e convergência do ciberespaço e, com isso, apresentar a estratégia criativa $^{11}$ ao consumidor, no ambiente virtual, no chamado momento zero da verdade (ou zero moment of truth ZMOT). ${ }^{12}$ O ZMOT é o momento quando o consumidor pega seu computador tipo laptop, celular ou algum outro dispositivo conectado à Internet e começa a se informar sobre um produto ou serviço que está pensando em experimentar ou comprar. E, em seguida, efetua a decisão de compra (LECINSKI, 2011, p. 10). Conforme as palavras de Rishad Tobaccowala:

\begin{abstract}
Quando os consumidores ficam sabendo de um produto hoje, sua primeira reação é "Vou pesquisar na Internet”. E assim eles embarcam em uma jornada de descobertas: sobre um produto, um serviço, um problema, uma oportunidade. Hoje você não está atrás de seus concorrentes. Você não está atrás da tecnologia. Você está atrás do seu consumidor (TOBACCOWALA, 2011 apud LECINSKI, 2011, p. 9, grifo nosso).
\end{abstract}

$\mathrm{Na}$ fase de introdução do ciclo de vida, a venda de um produto tende a um aumento lento. Antes de iniciar os investimentos em comunicação, pode-se valer da ferramenta do ciberespaço chamada brandseye (Figura 8) para se saber como as marcas concorrentes estão estabelecidas com suas participações no mercado (market sha-

${ }^{10}$ Definimos oportunidade de marketing como uma área de necessidade e interesse do comprador, cuja satisfação dá à empresa uma alta probabilidade de obter um desempenho lucrativo (KOTLER, 1999, p. 55).

${ }^{11}$ A estratégia criativa lida com o que a campanha vai comunicar, ou seja, com a mensagem transmitida para o público ou mercado-alvo. Na maior parte das vezes, a estratégia criativa é o aspecto mais importante da campanha de propaganda e, portanto, geralmente é orientada para detalhes (OGDEN; CRESCITELLI, 2010, p. 59).

${ }^{12} \mathrm{O}$ momento zero da verdade (ou Zero Moment of Truth ZMOT) influencia quais marcas entram na lista de compras, onde os compradores preferem comprar e com quem podem compartilhar os resultados. Cabe a nós entrar nessa conversa, neste novo momento em que as decisões são tomadas e fornecer as informações pelas quais os compradores estão ávidos de todas as maneiras (LECINSKI, 2011, p. 7). 
$r e^{13}$ dos concorrentes), os artifícios cognitivos da propaganda concorrente e o grau de credibilidade das marcas concorrentes e da própria marca na mente do consumidor (share of mind). As ações em cada job são no sentido de apresentação da comunicação da marca ou do produto, as demais assessorias preparam explicações iniciais com foco de apresentação, vantagens, e apresentação da logomarca. As principais características dessa fase são: o grande potencial de crescimento; a pouca participação de mercado, o pouco volume de vendas; a pouca rentabilidade e o alto investimento em comunicação e pesquisa ${ }^{14}$ (PINHEIRO; GULLO, 2009, p. 41).

A propaganda está focada, no ciberespaço, para a apresentação de algo recém-criado, inovador, singular e que mereça a atenção da partição do público-alvo que apresenta qualquer grau acesso ao ciberespaço. Com esse pensamento, faz-se necessário o foco na característica de sinergia de forma a integrar as mensagens propagandísticas para o consumidor em questão, evitando a duplicidade de entendimentos.

Figura 2 - A ferramenta BrandsEye e a credibilidade da marca UniCEUB, no ciberespaço

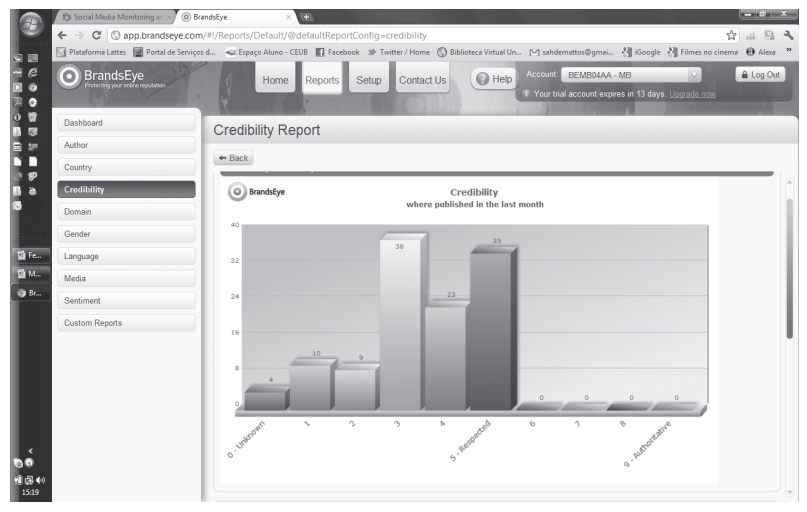

Fonte: http://www.brandseye.com/

Adicionalmente, para atender a essas demandas, a inserção da propaganda no ciberespaço, nessa fase do

${ }^{13}$ Chama-se market share ao estudo da participação de uma organização ou empresa no mercado. Toma-se como base o mercado total antes e depois do esforço de propaganda. (TAVARES, 2011, p.1). É a medida de aferição do grau de participação de uma marca ou produto no mercado, em dado momento (RABAÇA; BARBOSA, 2001, p. 471).

${ }^{14}$ A American Marketing Association antes definia a pesquisa de marketing como sendo a identificação, coleta e análise de dados para auxiliar na tomada de decisões de marketing (produto, preço, distribuição e comunicação) e hoje a define como sendo a função que liga o consumidor, o cliente e os demais públicos ao profissional de marketing e de comunicação por meio da informação (PINHEIRO; GULLO, 2009, p. 44). ciclo de vida do produto-marca, as ações devem priorizar a compra de espaços de propaganda em redes sociais, a compra de outdoors virtuais em espaços sociais de realidade virtual com o uso de jogos e programas que atuem no multiverso, como no Second Life; a compra de espaços de propaganda nos buscadores ${ }^{15}$ da internet, a exemplo do Google Adsense; a colocação de vídeos propagandísticos no youtube e a divulgação de propaganda na ferramenta Instagram, bem como a utilização de e-mails para divulgação de cartazes virtuais e folder ${ }^{16}$ virtual.

Nessa fase, os feedbacks das demais assessorias, postados no job, são importantes para dosar a intensidade propagandística e medir a aceitação do público-alvo com relação ao que foi apresentado nas ações de comunicação organizacional. Com isso, podem-se fazer modificações e correções iniciais na apresentação da comunicação da marca ou do produto e se pode ter uma noção de como a mídia vê as ações propagandísticas iniciais. A troca de informações entre as assessorias em cada job estabelecido, nessa fase inicial, é primordial para controle das ações em curso.

$\mathrm{Na}$ fase do crescimento, que se segue, a venda aumenta rapidamente e o produto se consolida. Essa fase tem como principais características: a formação da personalidade e da imagem da marca; a boa rentabilidade; o alto investimento em comunicação; a estabilização dos custos de pesquisa; a taxa de crescimento rápido; o aumento da ação da concorrência; o aperfeiçoamento do produto e a ampliação dos canais intermediários (PINHEIRO; GULLO, 2009, p. 41-42).

Nessa fase, o aproveitamento do ciberespaço se faz para ajustes de aplicação de propagandas virtuais confor-

${ }^{15}$ Pesquisa por meio da internet feita com os recursos de hipertexto, a partir de palavras-chave, por meio de banco de dados, online. Diz-se do software ou do conjunto de recursos técnicos que viabiliza esse tipo de pesquisa. Sistema capaz de indexar o conteúdo de páginas da web, possibilitando links para os respectivos sites. Diz-se do serviço de pesquisa oferecido por determinados sites. Pode ser restrito a temas específicos, conforme a área de conteúdo do site, ou ser aberto a qualquer tema e qualquer idioma. Diz-se do site especializado nesse mecanismo de pesquisa. Os principais sites de busca (como Altavista, Yahoo, [Google] etc.) oferecem conexões (links) para milhões de páginas da web em todo o mundo, atualizadas diariamente (RABAÇA, BARBOSA, 1999, p. 84).

${ }^{16}$ Volante, prospecto ou folheto constituído por uma só folha impressa, com duas, três ou mais dobras (RABAÇA, BARBOSA, 1999, p. 315). 
me os resultados apresentados pela ferramenta Brandseye. Com os ajustes implementados, segue-se a verificação da concorrência nessa mesma ferramenta virtual e a possível passagem da liderança do job para a assessoria de RP, de modo a iniciar as ações de oposição a concorrentes, se for o caso, no site da organização e em redes sociais. Esses ajustes visam aos apelos afetivos gerados dentro do ciberespaço em redes sociais e demais recursos da virtualidade que a organização lançou mão na fase anterior.

Figura 3 - propaganda comprada no ciberespaço

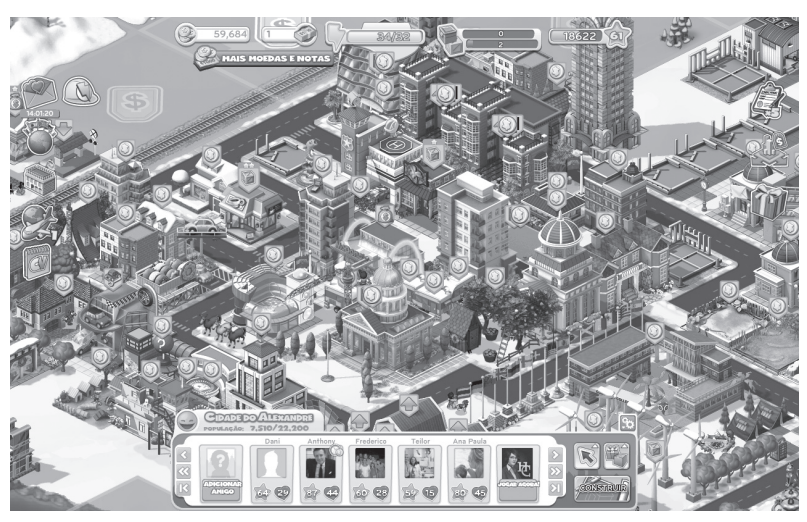

Fonte: http://apps.facebook.com/cityville/?ref=bookmarks\&co unt=2\&fb_source=bookmarks_apps\&fb_bmpos=1_2

$\mathrm{Na}$ fase da maturidade, a mais longa do ciclo de vida de um produto, o volume de venda é grande e estabilizado e suas características compreendem: o estabelecimento de novos usos para o produto conforme o apelo comportamental do consumidor; pode-se ter mais de uma marca para o produto; surgem novas características comportamentais inerentes ao produto; aumento da segmentação de mercado e dos canais intermediários; o preço pode ser diminuído para aumentar a conquista de mercado; boa rentabilidade; maior pico do volume de vendas; estabilidade do investimento em comunicação, boa imagem de marca; e sua melhor participação de mercado (PINHEIRO; GULLO, 2009, p. 42).

Por apresentar a melhor relação custo-benefício, é aconselhável a utilização, nessa fase, do chamado marke- ting viral ${ }^{17}$ nas redes sociais do ciberespaço, com o foco principal em aspectos comportamentais do consumidor que demonstraram, até então, suas preferências, preocupações a escolhas dentro da apresentação do produto no ciberespaço, diferenciando-o do concorrente. Além disso, o encaminhamento de e-mails propagandísticos permanece como ação possível nessa fase. Deve-se tomar o cuidado de evitar incorrer em spams. ${ }^{18}$

Finalmente, na fase de declínio, as vendas caem rapidamente; a liquidação de estoques é feita mediante generosos descontos; cessam os investimentos em comunicação e pesquisa e procura-se apurar todo e qualquer lucro remanescente possível; e o investimento passa a ser no desenvolvimento de novos produtos (PINHEIRO; GULLO, 2009, p. 42). Nessa fase, pode ser considerada a passagem de liderança em cada job para a assessoria de imprensa de modo a proporcionar que efeitos negativos de comentários de jornalistas possam ter reação rápida, antes da passagem da liderança de volta para a assessoria de publicidade e propaganda. Segundo o ciclo de vida do produto-marca e as ações de comunicação dispostas

${ }^{17}$ Modalidade de marketing baseada na divulgação boca a boca, feita pelos próprios clientes (consumidores, usuários, leitores etc.) junto a seus conhecidos. Essa técnica pressupõe credibilidade e segue os critérios do marketing de permissão, distinguindo-se, portanto, da prática de spam. [...] O marketing viral pode ser um poderoso recurso para a formação de redes de contatos. Seu nome refere-se à forma de disseminação (reproduz-se como um vírus, no bom sentido). Alguns profissionais preferem a expressão marketing de contágio (RABAÇA; BARBOSA, 2001, p. 471).

${ }^{18}$ Mensagem não solicitada. Abrange o chamado junk mail (lixo de correspondência) e o UCE Unsolicited Commercial E-mail). Costuma ocorrer principalmente na forma de correspondência eletrônica (e-mail) contendo ou não mensagem publicitária, expedida sem solicitação ou consentimento dos destinatários (mesmo que estes não sejam em grande número). Ocorre também no envio de mensagens fora do contexto, ou ainda em quantidade ou frequência excessiva para uma lista de discussão, newsgroup ou fórum e na colocação de usuários em um mailing list sem um prévio consentimento daqueles, o que implica geralmente a necessidade de cancelamento da assinatura para interrupção do recebimento das mensagens. [...] No entanto, existe uma série de desvantagens no uso do spam com objetivos de marketing: as reclamações dos usuários, que podem resultar em advertências, cancelamentos de e-mails, e até mesmo desativação de páginas da internet; necessidade de atender com presteza a todos os pedidos de remoção de nomes existentes no mailing list; a dificuldade de atendimento personalizado; o grande tráfego de dados na rede devido ao acúmulo de mensagens; e principalmente os prejuízos causados à imagem da empresa em função do envio de mensagens não solicitadas (RABAÇA; BARBOSA, 2001, p. 691, grifo nosso). 
em jobs, as assessorias de comunicação organizacional podem alternar-se na liderança de cada tarefa conforme cada fase ou conforme a necessidade de demandas e de atendimento do Plano de Comunicação da organização (Figura 16):

Figura 4 - Revezamento de liderança do job disposto no ciberespaço, conforme as fases do ciclo de vida do produto-marca

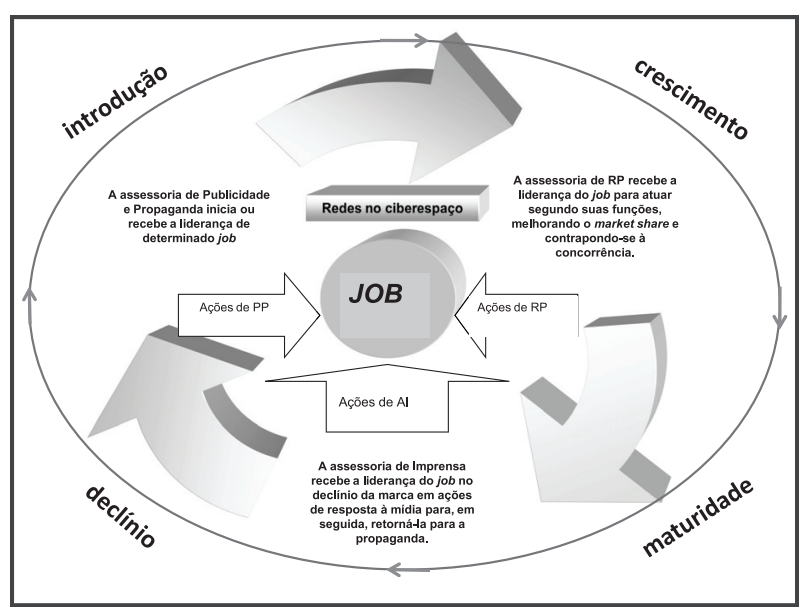

Figura nossa:

Com o exposto na figura acima, pode-se visualizar como ocorre a passagem, de modo formal, da liderança de cada uma das três assessorias da CIM, em atendimento às necessidades do job, disposto no ciberespaço, conforme as características apresentadas em cada uma das fases do ciclo de vida do produto-marca.

No início, quando uma marca, um produto ou serviço é lançado ou relançado no mercado, a assessoria de publicidade e propaganda assume a liderança do job, no ciberespaço, de modo a formar, com o afluxo de mensagens propagandísticas, as bases virtuais para alavancar a conquista de market share.

Com o volume de vendas sugerindo a entrada nas fases de crescimento e maturidade do ciclo de vida do produto-marca, maiores serão as demandas de relações públicas, principalmente nas redes sociais no ciberespaço; portanto, a passagem formal da liderança da assessoria de publicidade e propaganda para a assessoria de relações públicas é recomendável.

Ao final da fase de maturidade, e com o declínio das vendas, as demandas de jornalistas quanto à manutenção do lucro, balanços financeiros, providências para revitalização, recall, produção de uma nova versão do produto, ou reengenharia da marca, do produto ou do serviço; com questionamentos nem sempre amigáveis, o esforço de comunicação passa seu foco do público-alvo para a imprensa. Nessa fase, a liderança do job, no ciberespaço, deve ser formalmente passada para a assessoria de imprensa, de modo a dar vazão às mensagens que têm foco no relacionamento com a imprensa e a mídia.

Se for o caso de haver uma reengenharia, um recall ou uma revitalização da marca, do produto ou do serviço, é aconselhável que a liderança do job no ciberespaço seja devolvida à assessoria de publicidade e propaganda, uma vez que um novo ciclo de vida do produto-marca estará tendo início e o ciclo de passagem de liderança entre as assessorias componentes da CIM ocorrerá novamente, respeitando a mesma ordem.

Essas lideranças consecutivas de cada uma das assessorias não impedem que as ações das assessorias que, no momento, não detêm a liderança no job, tenham andamento. Muito pelo contrário, uma vez que estão desobrigadas da liderança, suas ações podem antecipar a assunção de liderança que se seguirá.

Esse círculo virtuoso, possibilitado pelas características de sinergia e convergência proporcionadas pela inserção do job no ciberespaço, fará com que haja um diferencial positivo de imagem organizacional percebida pela interação das mensagens de comunicação corporativa. Com isso, essas mensagens são dispostas no ciberespaço de modo complementar e respeitando os ditames do planejamento estratégico organizacional.

\section{A assessoria de imprensa relacionando-se com os jornalistas no ciberespaço}

A Assessoria de Imprensa (AI) pode ser considerada, dentre as três assessorias da CIM, a área mais sensível da comunicação organizacional por ser essencial como mediadora da comunicação da organização com o grande público, a opinião pública e a sociedade, via mídia impressa, eletrônica e, principalmente, a internet (KUNSCH, 2003, p. 169). Essa mediação pode ter características "emprestadas" da assessoria de RP ou ter características voltadas para o mercado, "emprestadas" da assessoria de publicidade e propaganda, dependendo de cada caso de mediação com a imprensa. 
A organização faz parte de um sistema de comunicação ${ }^{19}$ aberto, ou seja, que interage com elementos exteriores aos contidos dentro de si, com os quais ela tem que se relacionar para existir. Por isso, sua atuação no ciberespaço, em consonância com os jobs estipulados no Plano de Comunicação da organização, é vital para a manutenção da credibilidade da marca e, com isso, as características de sinergia e convergência são exploradas em seus processos. Sua aplicação se dá por meio de estratégias, técnicas e instrumentos pensados e planejados minuciosamente, com vistas na eficácia da comunicação com o jornalista, tendo este último como elo multiplicador da comunicação da organização (KUNSCH, 2003, p. 169).

A comunicação com os jornalistas, protagonizada pelo assessor de imprensa, é o que se costuma designar de "relacionamento com a mídia":20

\begin{abstract}
O assessor de imprensa é, hoje, um elemento fundamental na política de comunicação das empresas. É ele quem intermedeia as relações entre o staff das organizações e o público externo; atende aos jornalistas, facilitando-lhes o trabalho, exerce uma estratégia sadia de lobby junto ás comunidades de interesse da empresa; assessora os diretores e a presidência; alimenta áreas estratégicas com informações que coleta no ambiente exterior; interpreta climas; analisa oportunidades e contribui para o processo de tomada de decisões (BUENO, 1984, p. 4 apud KUNSCH, 2003, p. 191).
\end{abstract}

Alie-se a isso o fato de que, para dar divulgação para as ações de responsabilidade socioambiental

\footnotetext{
${ }^{19}$ Conjunto integrado de normas, material e pessoas, engajados a um planejamento de comunicação de modo a estabelecer uma unidade de mensagem, evitar a dispersão de meios e esforços, dar visão geral e integral dos problemas e maior objetividade na consecução dos objetivos (RABAÇA; BARBOSA, 2001, p. 682).

${ }^{20}$ No Brasil, usam-se os termos "imprensa" e "mídia” como sinônimos. Isto é, não se restringe o termo "imprensa" apenas aos veículos impressos, mas englobam-se nele, também, os meios eletrônicos. "Mídia” vem do latim media, plural de medium - meio. Já é usual no país o uso de "a mídia”, no singular e no gênero feminino, em vez de "os medias", para designar o conjunto de meios ou veículos de comunicação: jornais, revistas, rádio, televisão, etc. (KUNSCH, 2003, p. 190).
}

corporativa, ${ }^{21}$ as organizações não podem prescindir de um trabalho sistematizado de comunicação, capaz de fornecer subsídios para um relacionamento eficaz com seus públicos, que se atingem eficientemente só pelos meios de comunicação massivos, via mídia (KUNSCH, 2003, p. 191).

Ao se utilizar do ciberespaço como meio para relacionar- se com a mídia, a AI deve pautar seus produtos no fato de que as mídias constituem uma instância intermediária para atingir o público-alvo que não promulga nenhuma regra de comportamento, nenhuma norma, nenhuma sanção. Mais que isso, as mídias e a figura do jornalista não têm nenhuma intenção de orientação nem de imposição, declarando-se, ao contrário, instância de denúncia do poder (CHARAUDEAU, 2010, p.18). Com isso, a AI inicia um mapeamento dos contatos com jornalistas produzindo uma lista de e-mails e demais dados de contato que se chama mailing list. Sua constante atualização permite o contato com os jornalistas, associada ao estabelecimento de um endereço de e-mail institucional e dedicado ao atendimento às demandas da mídia. Tal $e$ -mail deve ser de ampla divulgação em site institucional, no facebook, twitter e demais redes sociais de relacionamento com o público.

Há também a necessidade de criar locais no facebook e twitter próprios e dedicados ao relacionamento com a mídia. A utilização das redes sociais no ciberespaço pela AI, nesses locais, deve levar em conta que as mídias são criticadas por constituírem um quarto poder dentro do Estado. O cidadão aparece com frequência como refém delas, tanto pela maneira como é representado, quanto pelos efeitos passionais provocados. Efeitos esses que se acham muito distantes de qualquer pretensão à informação (CHARAUDEAU, 2010, p. 17).

O discurso da mídia nessas redes se baseia no mais elementar funcionamento do ato de comunicação, no sentido de que este último depende da relação de in-

21 “[...] todas essas ações que visem a promover a melhoria da qualidade de vida e da qualidade ambiental de forma conjunta e integrada às necessidades e expectativas humanas, como proteção ao meio ambiente, proteção social, saúde, educação, lazer, organização do trabalho, são ações que se caracterizam como transformadoras e, por isso, socialmente responsáveis. Responsabilidade social corporativa dos gestores é a obrigação de estabelecer diretrizes, tomar decisões e seguir rumos de ação que são importantes em termos de valores e objetivos da sociedade" (NASCIMENTO; LEMOS; MELLO, 2008, p. 183). 
tencionalidade que se instaura entre as instâncias de produção e de recepção do texto. Isso determina três lugares de pertinência que a AI deve observar no ciberespaço: o da instância de produção, submetida a certas condições (técnicas em sua maioria) de produção; o da instância de recepção, submetida a condições de interpretação (psicossocial em sua maioria); o do texto como produto, que se acha, enquanto tal, submetido a certas condições de construção (CHARAUDEAU, 2010, p. 24).

Com isso, o universo de atuação da AI no ciberespaço deve ter especial foco na construção do texto apresentado nas redes sociais, evitando efeitos passionais negativos e vislumbrando como a Imprensa buscará a interpretação desse texto para produzir seus efeitos desejados no ciberespaço. Analisar as condições de produção de textos midiáticos no ciberespaço depende de uma semiologia que busca efeitos esperados com os meios técnicos que dispõe. As condições de interpretação dos textos midiáticos no ciberespaço pela instância de recepção, por sua vez, implicam em uma análise psicossociológica que pretende interrogar a natureza e o comportamento dos públicos-alvo. Por último, o produto do texto midiático no espaço virtual será um somatório de análises que remontam a uma cointencionalidade que compreende distinguir os efeitos visados, os efeitos possíveis e os efeitos produzidos. Esse foco é de vital importância na articulação das consequências que o texto midiático irá produzir na imagem percebida pelo público, analisando os efeitos sobre este último.

As ferramentas brandseye e socialmetrix, apresentadas anteriormente, também podem ser de grande ajuda para o estabelecimento de qual rede social é mais relevante para a organização e, com isso, determinar onde o esforço da assessoria de imprensa será mais concentrado de modo a aumentar o universo de atuação da organização, melhorando, com isso, sua credibilidade e contribuindo para a melhoria da imagem institucional.
Figura 5 - Utilização da ferramenta Brandseye para pesquisa de que mídias estão mais envolvidas com a organização.

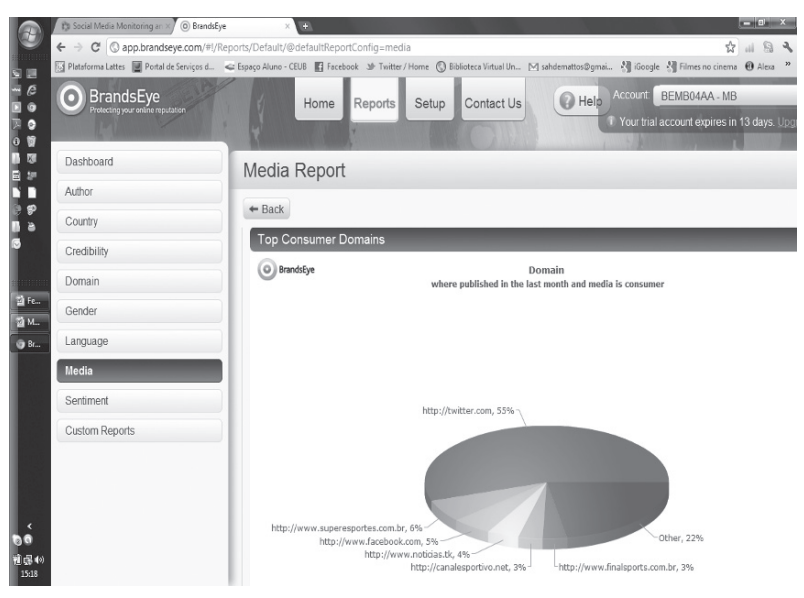

Fonte: http://www.brandseye.com/

Os e-mails, e links para redes sociais de relacionamento com a mídia devem ser direcionados também a uma sala de imprensa virtual e de caráter institucional.

Figuras 6 - Um exemplo de uma sala de imprensa virtual: Empresa Vale do Rio Doce

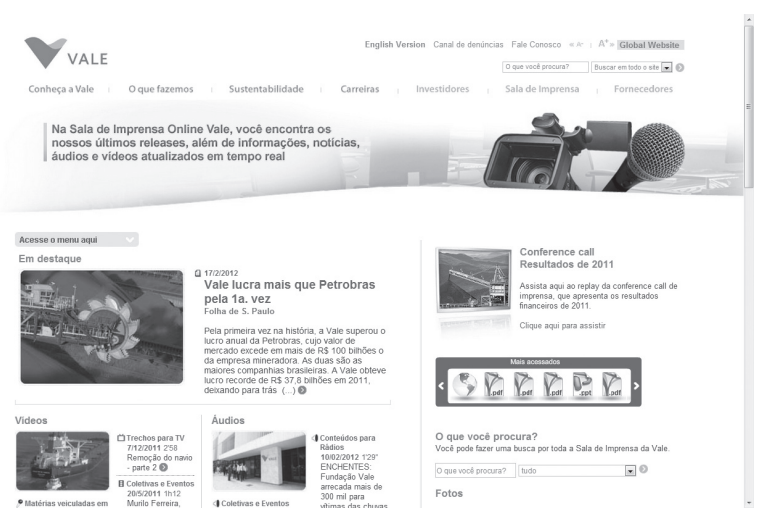

Figuras 7 - Um exemplo de uma sala de imprensa virtual: Empresa Vale do Rio Doce

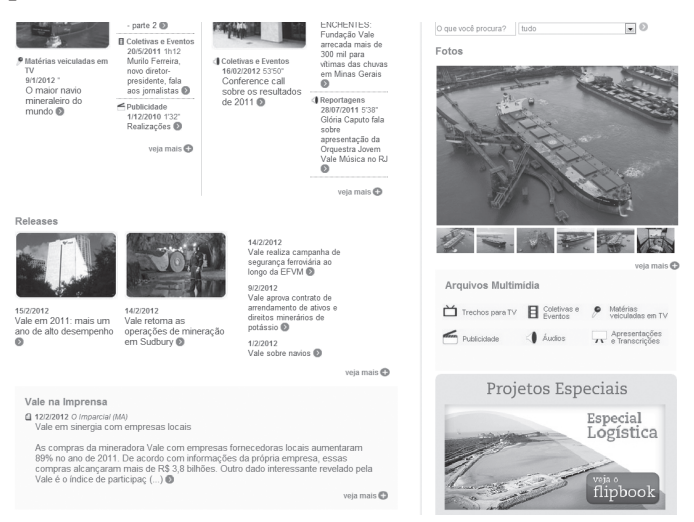

Fonte: http://saladeimprensa.vale.com/pt/home/imprensa.asp 
A sala de imprensa virtual deve respeitar os principais jobs dispostos pelas demais assessorias da CIM de modo a proporcionar uma sinergia de esforços e integrar as mensagens já veiculadas pelas RP e propaganda. Deve também apresentar mensagens complementares às já divulgadas e de forma convergente com as mensagens de marca das demais assessorias. Essa sala de imprensa deve ser uma subdivisão do site institucional e deve conter os principais produtos da assessoria de imprensa dispostos para a consulta dos jornalistas. Quanto mais atualizada é a sala de imprensa institucional no site, mais confiável é sua reputação e menores serão os contatos por via telefônica, pois todos os assuntos relacionados com a organização já estarão dispostos para consulta dos jornalistas demandantes de informações da organização.

Os produtos que normalmente são mais dispostos em salas de imprensa virtuais são: notas de esclarecimento à imprensa, press releases, folderes virtuais, vídeos, links para as redes sociais organizacionais, divulgação de coletivas e eventos, conteúdos de áudio e para rádios, matérias veiculadas em televisão, fotos etc.

Adicionalmente ao estabelecimento de uma sala de imprensa virtual, pode-se disponibilizar uma sinopse de notícias da mídia relacionadas com a organização por meio da execução do serviço de clipping, devem-se utilizar os buscadores específicos que remetam os assuntos relacionados à organização com busca por palavras e expressões relacionadas à marca e a produtos da empresa para o acompanhamento da mídia.

Figura 8 - Utilização da ferramenta Brandseye para pesquisa de que mídias estão mais envolvidas com a organização: exemplo com o UniCEUB

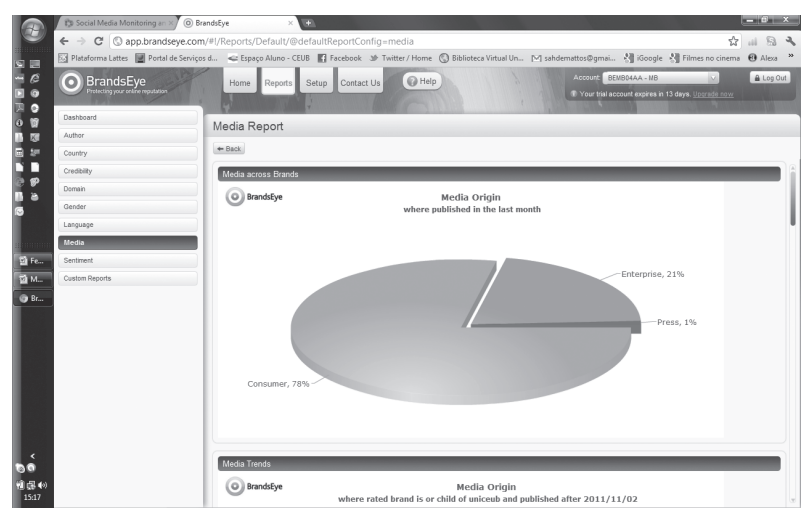

Fonte: http://www.brandseye.com/

Outra forma de atuação da AI é por monitoramento das redes sociais de forma a buscar o que se fala a respeito da organização. Pode-se, para isso, utilizar a ferramenta trendsmap, apresentada no capítulo 1 deste trabalho, aliada com o monitoramento simultâneo de mídias, possibilitada pela ferramenta hootsuite. Essa ferramenta reúne, em um mesmo software, a participação da organização em todas as redes sociais que faz parte:

Figuras 9 e 10 - Exemplo de utilização simultânea e monitoramento simultâneo das redes sociais twitter e facebook do usuário André Sá de Mattos, utilizando o hootsuite:
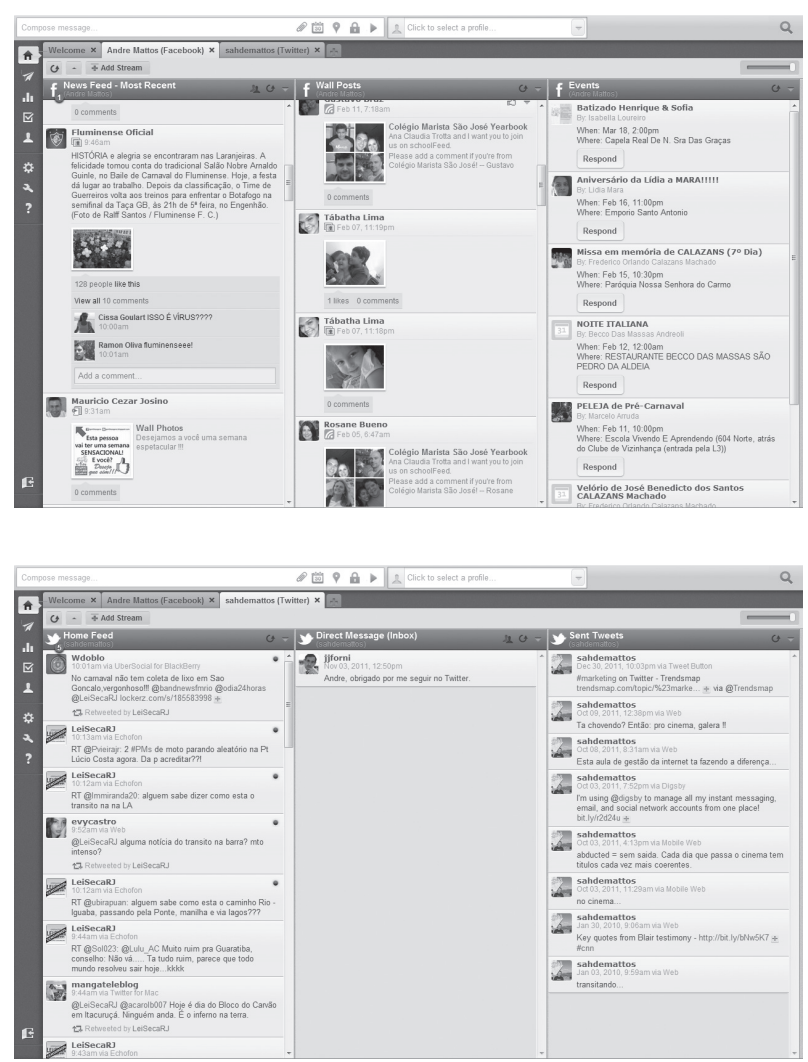

Fonte: http://hootsuite.com/dashboard\#/tabs?id=9824809

\section{Considerações finais}

Uma forma particular de utilização da virtualidade é sob a ótica da assessoria de publicidade e propaganda. As ferramentas brandseye, google adsense e instagram, aliadas ao e-mail propagandístico e ao marketing viral estabelecem meios e parâmetros para que o investimento em comunicação possa ser dosado conforme a fase do ciclo de vida do produto/marca. Essas ferramentas fazem com que as características de sinergia e convergência possam também ser utilizadas para proporcionar um diferencial positivo de imagem organizacional segundo o ciclo de vida do produto-marca. Além disso, fazem com que as ações de comunicação possam ser dispostas em jobs, com as assessorias de comunicação organizacional alternando-se na liderança de cada tarefa conforme cada 
fase ou conforme a necessidade e demandas de vendas e de atendimento, atuando segundo o Plano Estratégico da organização.

Outra forma particular de utilização das duas potencialidades discutidas é sob a ótica da assessoria de imprensa com a possibilidade de criação de espaços virtuais dedicados ao relacionamento com os jornalistas, mas evitando efeitos passionais negativos e vislumbrando como a Imprensa buscará a interpretação desse texto para produzir seus efeitos desejados no ciberespaço.

Pode-se concluir também que, ao estabelecer as potencialidades desse ambiente virtual a serem utilizadas conceitualmente em cada área da CIM, haverá condições e ferramentas para o "salto" de imagem da organização.

Somente assim as questões de comunicação que dia a dia se colocam diante do gestor podem ser resolvidas de forma a atingir a completude dos resultados em comunicação exigidos pelos públicos.

\section{Referências}

BACON, Jono. A arte das comunidades virtuais. Trad. Rafael Zanolli. São Paulo: Novatec , 2010.

CASTELLS, Manuel. A sociedade em rede: a era da informação: economia, sociedade e cultura. 3. ed. Trad. Roneide Venancio Majer. São Paulo: Paz e Terra, 1999. v. 1

CHARAUDEAU, Patrick. Discurso das mídias. Trad. Angela M. S. Corrêa. São Paulo: Contexto, 2010.

FACEBOOK. Cityville. Disponível em: <http://apps. facebook.com/cityville/?ref=bookmarks\&count=2\&fb_ source=bookmarks_apps\&fb_bmpos $=1 \_2>$. Acesso em: 20 fev. 2012.

HOOTSUITE. Social media manegent. The leading social media dashboard to manage and measure your social networks. Disponível em: <http://hootsuite.com/ dashboard\#/tabs?id=9824809>. Acesso em: 20 fev. 2012.
BRANDSEYE. Accurate insights for better decisions. Disponível em: <http://www.brandseye.com/>. Acesso em: 30 dez. 2011.

KELLER, Kevin Lane; MACHADO, Marcos. Gestão estratégica de marcas. Trad. Arlete Simille Marques. São Paulo: Pearson Prenticce Hall, 2006.

KOTLER, Philip. Marketing para o século XXI como criar, conquistar e dominar mercados. Trad. Cristina Bazán. São Paulo: Futura, 1999.

KUNSCH, Margarida M. K. Planejamento de relações públicas na comunicação integrada. 4. ed. São Paulo: Summus, 2003.

LECINSKI, Jim. ZMOT: Conquistando o momento zero da verdade. Chicago: Google Inc., 2011.

NASCIMENTO, Luis Felipe; LEMOS, Ângela Denise da Cunha; MELLO, Maria Celina Abreu de. Gestão socioambiental estratégica. Porto Alegre: Bookman, 2008.

OGDEN, James R.; CRESCITELLI, Edson. Comunicação integrada de marketing: conceitos técnicas e práticas. 2. ed. Trad. Cristina Bacellar. São Paulo: Pearson Prenticce Hall, 2007.

PINHEIRO, Duda; GULLO, José. Comunicação integrada de marketing: gestão de elementos de comunicação: suporte às estratégias de marketing e de negócios da empresa: fundamentos de marketing e visão de empresa. São Paulo: Atlas, 2009.

RABAÇA, Carlos Alberto; BARBOSA, Gustavo Guimarães. Dicionário de Comunicação. 2. ed. Rio de Janeiro: Elsevier, 2001.

TAVARES, Fred. Marketing: conceitos, tipos, objetivos e análise de desempenho. 2007. Disponível em: <http:// www.portaldomarketing.com.br/Artigos/Marketing_>. Acesso em: 23 dez. 2011. 
Para publicar na revista Universitas: Arquitetura e Comunicação Social, acesse 0 endereço eletrônico www.publicacoesacademicas.uniceub.br. Observe as normas de publicação, para facilitar e agilizar o trabalho de edição. 